\title{
Evaluación, por tratamiento digital de imágenes, del deterioro de monumentos. Metodología
}

\section{Monuments deterioration evaluation, using digited images. $A$ methodology}

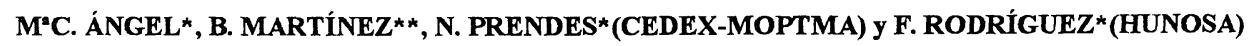

$\left.{ }^{*}\right)$ Licenciados en C. Geológicas, $\left.{ }^{* \star}\right)$ Ingeniero de Caminos Canales y Puertos

ESPAÑA

\section{RESUMEN}

En este trabajo se propone una metodología para el tratamiento de la información, integrando las técnicas de proceso digital de imágenes, la capacidad de análisis de los sistemas de referenciación gráfica y las bases de datos relacionales, referidas a monumentos.

Para ello se elaboran las imágenes base por algoritmos propios del proceso digital, incluyendo aquellas en una aplicación especifica que asocia cada capa a una base de datos con las propiedades petrofisicas, hidricas, etc., o bien entre si, dando lugar a mapas temáticos.

La generación de estos mapas permite abordar los problemas de restauración, rehabilitación o tratamiento de los diferentes espacios monumentales de forma global, con incidencia especial en las zonas más afectadas.

\section{SUMMARY}

In this work a metodology is proposed for data processing, integrating the techniques of digital images processing and the analytical capacity of graphical referencing systems and relational databases, in relation with the monuments.

The images are generated using the digital image processing and they are included into a graphical data processing systems associated with a database containing the caracteristics of the ashars or constituyent elements. By combination of the images with the database induced properties the information is processed. The results are thematic maps that we save such as images. These maps are layers of new information (deduced levels).

The elaboration of these maps allows to attack the problems of the restoration, renovation or treatment of the diferents monumental spaces on a global way, paying special attention on the most gravely affected areas.

\section{INTRODUCCIÓN}

La utilización de las técnicas de tratamiento digital de imágenes en la evaluación y diagnosis de patologías de edificios históricos se había centrado, hasta ahora, en la determinación de los parámetros petrográficos (1) (2) (3) (24), caracterización de la porosidad (4), etc., de los materiales constituyentes (19) (20). Asimismo, otros autores (5) (26), considerando el monumento en su conjunto, evaluaron, por comparación de fotografias obtenidas a lo largo del tiempo, los daños sufridos, mediante la técnica del "falso color", consiguiendo, con

\section{INTRODUCTION}

Until now the digital image processing techniques were used for materials for quantification of the porosity (4), linear features, discrimination of minerals phases and many other structural parameters. The frequency histogram of grey levels analysis on the texture (30) of the materials had detected the ashlar state in some monuments (24) (25). The evaluation and diagnosis of the pathologies, suffered by historical, buildings had been concentrated on determining the petrographical parameters (1) (2) (3) (24), the nature of the constituent 
ello, discriminar zonas sanas y alteradas (28) en superficie, de acuerdo con las texturas de los materiales (30) y sus patologías (24) (25); en algunos casos, además, se combinaron con imágenes de ultrasonidos (5).

El desarrollo de sistemas de tratamiento de información gráfica (6) (9) (18) permite combinar, por una parte, los daños de superficie del monumento, deducidos por análisis digital, con los datos aportados por otras técnicas (microscopía, ensayos hídricos, etc.) (2) (29), generando nuevas capas de información, (por integración de las anteriores) (7) o imágenes (equivalente a la técnica de multi-imagen) (8).

\section{GENERACIÓN DE MAPAS DE INFORMACIÓN}

\subsection{Tratamiento de la Imagen}

Para el estudio de los monumentos se parte del material fotográfico disponible, de los esquemas de los planos de obra "originales" (9), en los que figure la posición de cada sillar y de cualquier otro tipo de documentación, gráfica, existente del mismo (17) (27) (31).

Ambos se digitalizan, por escaner, corrigiendo, posteriormente, las pequeñas distorsiones que se han producido durante este proceso, adaptando y referenciándolos para homogeneizar sus escalas y facilitar los procesos de superposición de información (Fig. 1, a y b).

De la imagen digitizada del plano obtenemos la distribución y forma de los sillares en el momento de su construcción (9). De la fotografia, y por técnicas de restauración de la imagen (expansión lineal del histograma y aplicación de filtros matriciales) (10), deducimos los niveles de gris que corresponden a los bordes de los sillares que, generalmente, tendrán valores próximos a cero. Los valores máximos y mínimos de estos umbrales nos darán, por segmentación, la imagen binaria de los sillares en su estado actual, es decir, alterados (26).

A las dos nuevas imágenes de los sillares, originales y alterados, se les aplica un operador booleano tipo OR (extrae información común a ambas) deduciendo sus diferencias, que estarán localizadas, principalmente, en los bordes, siendo en algunos casos importantes, dependiendo, sobre todo, de su grado de deterioro (12) (18) (Fig. 1c).
(19) (20), etc. Moreover, considering the monument as a whole, other authors have evaluated (5) (26) the damages suffered using the "false colour" technique and comparing photographs taken over the years, managing to distinguish between healthy and altered areas on the surface, according to the texture of the materials and their pathologies. Additionally, in some cases, they also used ultrasonic images (5).

The development of graphical data processing systems (6) (9) (18) permits the combination on one hand about the superficial damage to the monument, noted by digital analysis, and on the other hand the information derived from other techniques (microscopy, water tests, etc.) (2) (29). By means of this technique we can generate new layers of information (by assimilating all the previous information) (7) or images (the equivalent of the multi-image technique) (8).

\section{INFORMATION MAP GENERATION}

\subsection{Image Processing}

In the study of the monuments we start with the available photographic material, the technical drawings of the "original" plans (9) in which the position of each ashlar is shown, and of any other kind of graphical documentation of the monument (17) (27) (31).

This material is digitized using a scanner, correcting, then, the slight distortions produced during the process, adapting and referencing them in order to coordinate the scales and make ease the superimposition process of information (Fig. l, a y b).

From the plan digitized image we obtain the original distribution and form of the ashlars in its building moment (9). From the photography, and from a image restoration proccess (linear spread of the histogram to full range and matrix filters application), we deduce the grey levels corresponding to the edges of the ashlars, generally near zero (10). From the maximun and minimun limits; setting in the segment process, we will obtain the binary image which correspond with the ashlars in its present state, that is altered (26).

The boolean operator type OR is applied to the two new images of the ashlars; the original and altered ones. It extracts information common to both and the differences are deduced, that will be principally placed on the edges and sometimes it is especially significant, depending, above all, on its deterioration grade (12) (18) (Fig. Ic). 


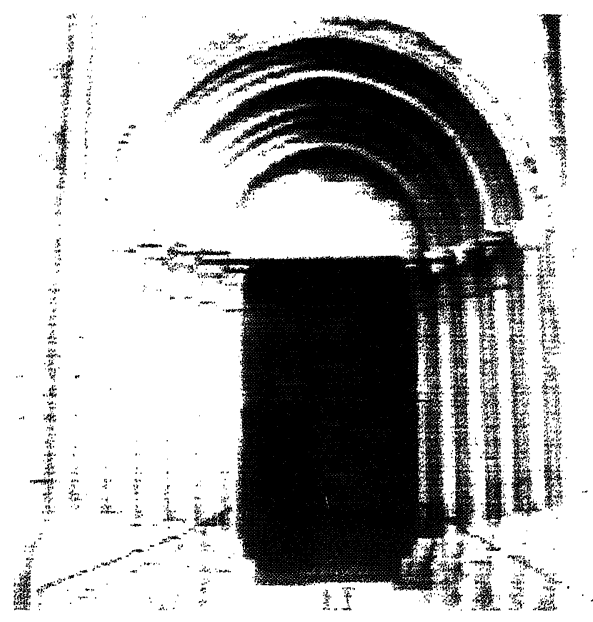

a

Imagen digitizada original. Portada principal de la iglesia de Santa Clara.

Original digitized image. Santa Clara church.

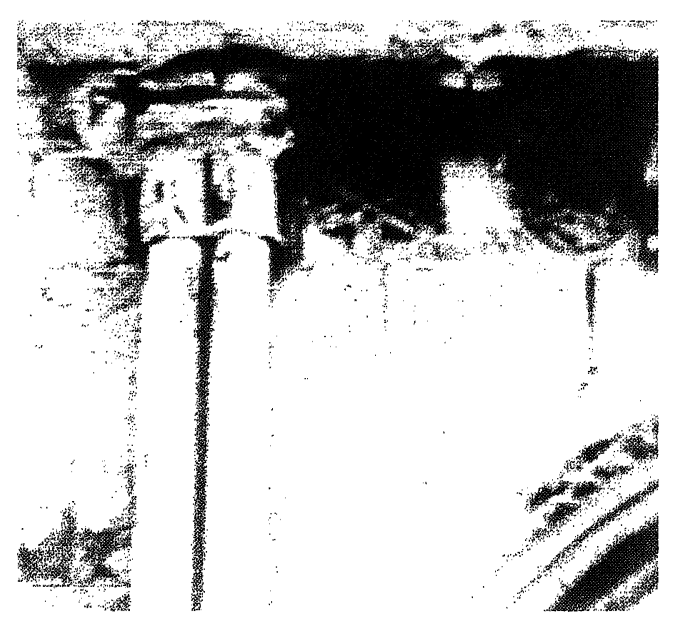

c

Detalle de la portada, con la distribución de los sillares y su patología.

Facade detail. The ashlars distribution and the most common pathology can be apreciated.

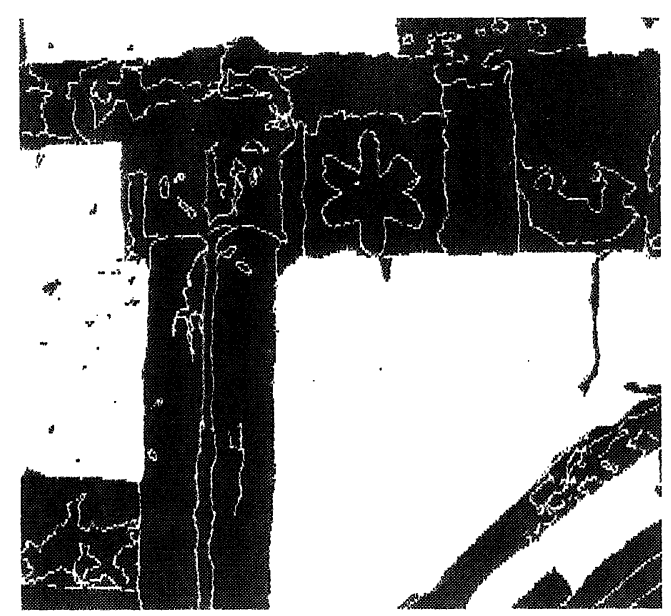

e

Mapa de litologías. Fin color claro, areniscas de tipo I; en color oscuro, areniscas de tipo II.

Litological level. Type Isandstone, in light colour and type II sandstone in dark colour.

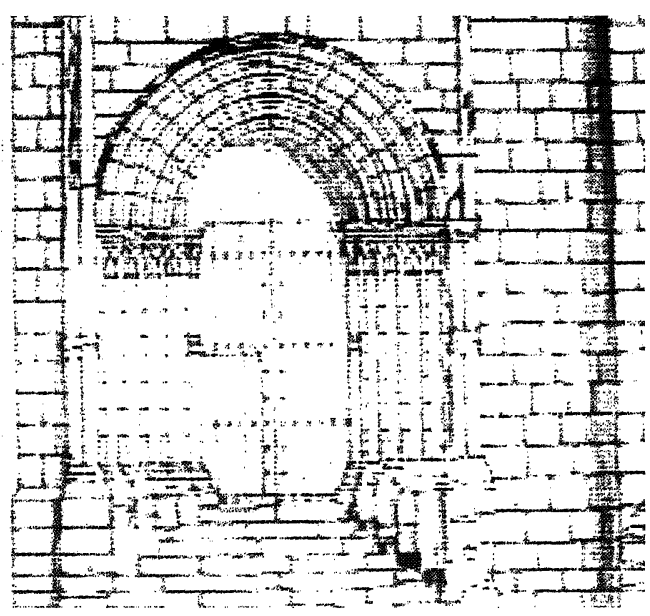

b

Plano de los sillares del monumento.

Technical drawing plan in which the position of each ashlars is shown.

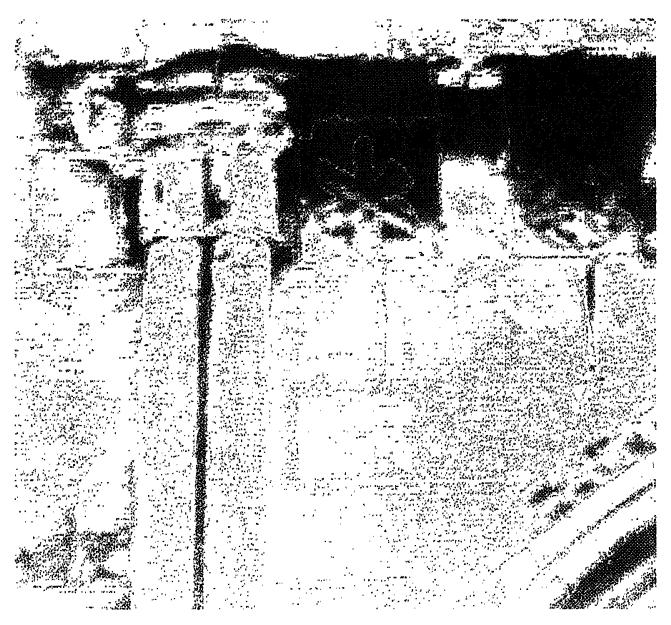

d

Imagen en falso color, con filtro tipo Sobel, para realzar los bordes de las texturas.

False colour image, after appling a Sobel gradient to enhance texture's edges.

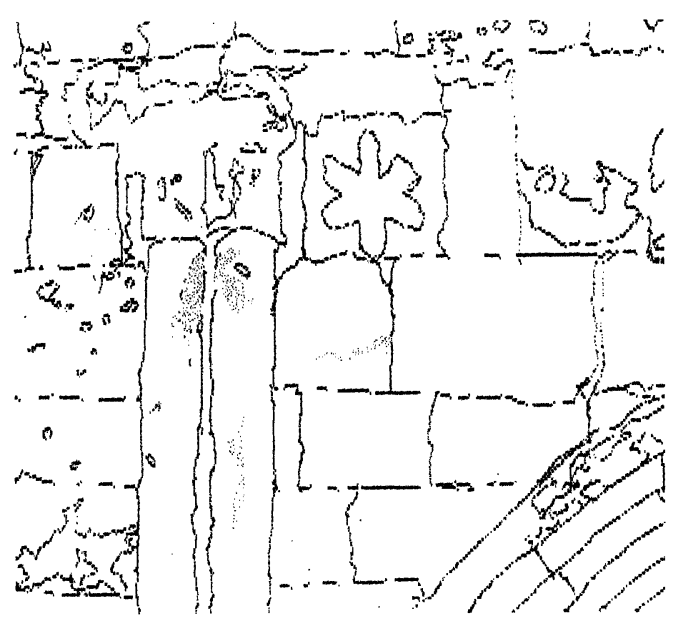

Combinación detresniveles de información e imagen resultante. lilnivel de porosidad, el litológico y el de alteración. La imagen final da la \%na más afectada (en tonos claros), así como las zonas que deben tratarse.

Three levels of informations are been combined: litology, degradation and porosity. The final image gives an area (lighter) which show signs of serious damage.

Fig. 1.- Proceso digital de imágenes aplicado a la iglesia de Samta Clara. / Fig.1.- Digital images processing. Santa Clara church. 
Para cuantificar este fenómeno (perdida de material o arenización -AR-), se realiza, sobre ellas, la operación booleana NOT (dando, por inversión de la imagen, el área de cada sillar) y sobre éstas se ejecuta el operador booleano XOR (extrae información no común), señalizando los pixels resultantes (11).

Este proceso da una primera imagen, que se esqueletiza, y que utilizamos como soporte de una capa de información (imagen de los bordes de los sillares en su estado actual); así como el porcentaje de pérdida de material que han sufrido (que se añadirá a un mapa de información para su tratamiento posterior) (23).

Sobre las fotografias originales, ya digitizadas, y en los tres planos de información $(R, G, B)$ que conforman la imagen color, se restaura aquella mediante el estudio del histograma de frecuencia de niveles de gris (10). El proceso a seguir es aplicar un algoritmo de normalización que mejora su contraste (expansión lineal de su histograma hasta los valores extremos) y, posteriormente, un filtrado de paso alto (realce de contornos) que redefine sus rasgos estructurales (12) (18).

El resultado final es una imagen en la que se ha acusado las diferencias entre sus elementos estructurales (bordes de sillares, fisuraciones, etc.).

Posteriormente, se realiza el análisis de los valores de cada sillar, o elemento a diferenciar, por perfiles de línea, extrayendo sus parámetros estadísticos (valor máximo, mínimo, media, etc.), y utilizándose, como umbrales de corte, posteriormente, en la segmentación, obteniendo una imagen clasificada (10) (13) (22).

Se ha visto, sin embargo, que estos rangos, para algunas litologías y/o patologías, se solapan, dando lugar a confusiones en la segmentación y, consecuentemente, en la discriminación adecuada de cada sillar o zona de interés a analizar. Este problema se ha resuelto ejecutando una segmentación binaria en las diferentes bandas, buscando las de menor grado de solapamiento. Así, por ejemplo, en el caso del material de la Fig. 2, los umbrales de corte se toman en el canal $\mathrm{R}$, mientras que en el otro material, estos se discriminan en el canal $B$. El resultado es una imagen clasificada, con diferentes colores, identificativos, cada uno de ellos, de cada litología (18).

Hemos de indicar, sin embargo, que en la imagen clasificada pueden quedar zonas indistintamente asignadas a dos litologías diferentes. La solución adoptada es ampliar estas zonas conflictivas (zooms), aplicar un algoritmo de linearización y segmentar, de nuevo, con los umbrales deducidos de este último proceso.

Posteriormente estas subimágenes se integran, por reducción, en la original (12).
The Boolean operator NOT (this inverts the image showing the area of each ashlar) is applied in order to quantify the phenomenon of material loss or grain disgregations - $\boldsymbol{A R}$ - and the Boolean operator XOR (this extracts the information which is not common) highlighting the resultant pixels (11).

This process gives us an initial image which is thinned by binary morphology tecniques and which we use as a base for an information overlay (an image of the contours of the ashlars in their present state), and the percentage material (which loss shall be added to an information map for later processing (23).

On the original digitized photographies, and in the three information levels $(R, G, B)$ which built the color image, is restored by studying the frequency histogram of grey levels (10). The process consist on the aplication of an algorithms of normalize which increase top of the contrast (linearly mapping the present grey levels into the full range of 0-255) and then the application of a highpass filter which redefines its structural characteristics (12) (18).

The final result is a enhance contour image, in which we have remark the diferences betwen its structural elements, (edges, ashlars, fisurations, etc.).

Then, the ashlar values or diferent elements, are clasified, applying lines profiles for each ashlar, obtaining the statistical parameters (maximum and minimum value) of the setting thresholds in order to apply in the segment process giving a clasificed image (10) (13) (22). The statistical treatment give rise for some ashlar at overlap in the grey levels limits.

This overlap produces confusion in the segment process (due to its grey common levels) and therefore in the adequate discrimination of each ashlar. This problem has been solved by using a discriminate two level on the different bands of the colour image. On three band of the image $R, G, B)$ we seek those with least overlap. For example, in Fig. 2, the setting thresholds for a rock material were taken from channel $R$ and for other diferent material were distinguished in channel B. As a result, we obtain a classified image with the grey levels of each lithologies (18).

However, it must be pointed out that there could be remained areas in the classified image which are indistinctly assigned to two different lithologies. The solution adopted was to amplify these conflictive zones (zoom up), apply a linearize algorithm and segment another time with the thresholds deduced from this last process. Once this is finished these subimages are reduced (zoom down) and integrated into the original (12). 
NÜMEROS DE PIXELS / NUMBERS OF PIXELS

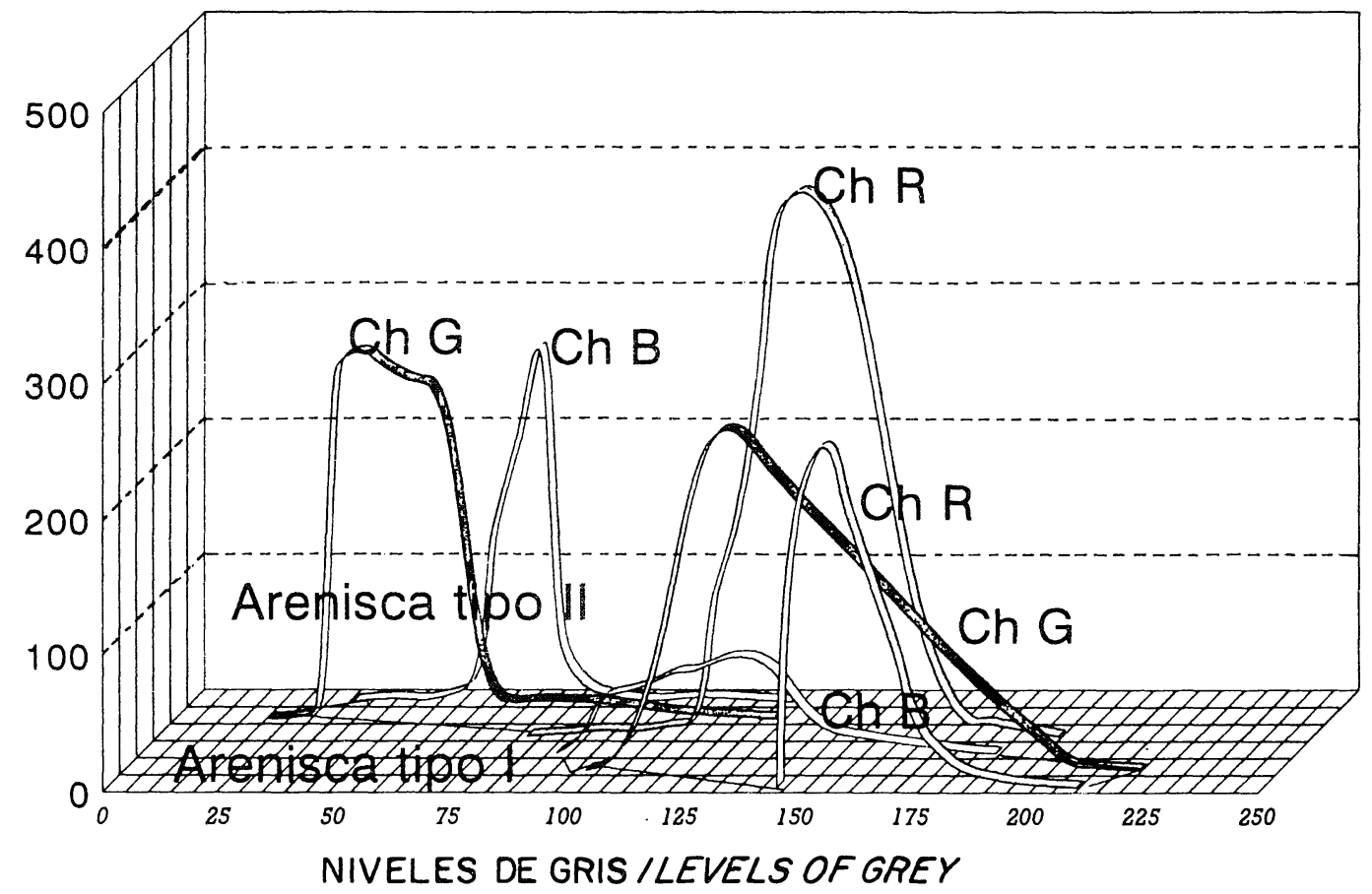

Fig. 2.- Histograma de los dos tipos de material que aparecen en la iglesia estudiada.

Fig. 2.- Histogram of two types on material on the studied church.

Las zonas que plantean problemas, y por lo tanto que tienen que reclasificarse por este procedimiento, se corresponden a lugares de edificio donde la incidencia de las sombras es mayor, y hay una mayor homogeneización de los niveles de gris que conforman esta parte de la imagen (23).

Es interesante, una vez realizado este proceso, comparar los resultados que hemos obtenido con la imagen original, comprobando así el grado de acierto en la clasificación (9).

En el caso de que éste no fuera el adecuado, repetiríamos el proceso, diseñando nuevos algoritmos y procesos de clasifícación. Si el porcentaje de acierto fuera aceptable, podemos corregir los pequeños errores generados de forma interactiva, por reasignación manual de los niveles de grises obtenidos erróneos.

Todo este proceso da una segunda imagen, que corresponde a una nueva capa de información, en la que se identifican las litologías del monumento (16).

Para obtener la cartografía de la alteración se aplican dos procesos diferentes a la imagen, ya restaurada (9) (22) (26). El primero de ellos consiste en redefinir el
Those areas which caused problems, and so had to be reclassified using this process are corresponded to places of the building where the shadow incidence is bigger, and there is a large grey levels homogenization which make up this area (23).

It is of interest, when the process is concluded, to compare those results with the original image checking thus the success in the clasification (9).

If it is inadequated, we will repeat the process, developping new algoritms and clasification process. If the sucess rate is aceptable, we can connect the small errors generated in a interactive way, by manual reasignation of the wrong grey levels.

From this process we obtain a second image, which corresponds to another layer of information, and in which the monument's lithologies can be identified (16).

In order to obtain a map of the alteration, the two different processes are applied to the image now restored (9) (22) (26). The first involves the change of 
histograma de frecuencia de niveles de gris mediante un escalado (10), centrándose en los niveles inferiores, evidenciando así pequeños cambios de color en el material, logrando una mejor discriminación en las variaciones, a veces sutiles, de los niveles de gris. A continuación, se aplican zooms (resolución $50 * 50$ pixels) consecutivos de toda la imagen, aumentando la fiabilidad de la discriminación. Sobre estas subimágenes, y por segmentación, obtenemos una imagen clasificada (compuesta por las anteriores subimágenes), con las distintas decoloraciones del material (5) (como es el caso de los enmugrecimientos -EN- y las pátinas -PT-); la diferencia entre ambas, por ordenador, no es posible, por lo que se incluyen en el mismo grupo.

El segundo proceso es operar sobre los rasgos geométricos de la imagen, remarcando las diferencias entre los valores de gris próximos (operaciones de área) (13). Los filtros aplicados, en este caso, son de tipo SOBEL normalizado (que nos define sólo la existencia de bordes dentro de la imagen) (13) (Fig. 1d).

Con este algoritmo se extraen tanto los bordes de cada sillar como su textura (5); el resultado es una imagen que, después de segmentarla, da los elementos geométricos (entendiendo por tales las irregularidades del sillar, como bordes, fisuraciones, acanaladuras, etc.).

La resta de esta imagen y de la primeramente deducida da, solamente, los rasgos internos de los materiales, conteniendo todos los fenómenos alterológicos que inciden y condicionan la textura (alvéolos, desplacaciones). La diferenciación entre un tipo u otro de textura puede hacerse aplicando algoritmos propios de la morfología binaria (14). Así, con esta imagen, y eliminando, por criba experta, objetos alargados (cuyo factor de forma esté por debajo de 0,4) tendremos las zonas de alveolización (AV) y picaduras (PI), que suelen tener formas globulares o circulares $\left(\mathrm{F}_{\mathrm{fc}}\right.$ altos); invirtiendo el proceso de criba experta $\left(\mathrm{F}_{\mathrm{fc}}>0,4 \%\right)$ quedarán los estriados (ET), acanaladuras (AC), fisuraciones (FS) y desplacaciones (DP).

Todo este proceso genera varias imágenes; La primera con EN y PT, a la que se reasigna un nuevo color; la segunda, con zonas de AV y PI, con otro color diferente y la tercera, con zonas de ET, AC, FS y DP, que, al igual que las anteriores, se le asigna un nuevo color. Estas imágenes se integran en un único recinto de memoria, por procesos de suma (11), obteniendo una sola con la cartografia de las formas de alteración en el monumento.

Normalmente, y debido a que los AV y PI aparecen como áreas de poco tamaño, para facilitar su seguimiento se marca todo el sillar, dependiendo, por supuesto, de la escala de trabajo y resolución con la que estemos operando. histogram at the grey levels values (10), concentrating on the lower levels to put in evidence slight colour changes in the material, achieve a better differentiation of the variations, sometimes subtle, in grey levels. After this, the total image is progressively zoomed to a resolution of $50 * 50$ pixels increasing the effectiveness of the differentiation. This process scans those areas affected by colour changes in the stone (5) (as is the case of blackening (EN) and patina (PT)). The differentiation between these two using the computer is impossible, so they are included in the same group.

The second process involves the operation on the geometric details of the image distinguishing limits between similar grey levels (area operations) (13). The filters applied in this case are of the SOBEL gradient normalized type (which only highlight the existence of contours within the image) (13) (Fig. 1d).

With this algorithm both the contours and the texture of each ashlar are extracted (5). The result is an image which, after been segmented, provides the geometric characteristics (understood to be the irregularities of each ashlar, such as edges, fissures, grooves, etc.).

Taking this image away and the image deduced before it is only showed the internal characteristics of the materials, which contain all the alteration phenomenons that influence and condition the texture (alveolar erosion, plaques). The difference between one type of texture and the other can be met by applying binary morphology algorithms (14). In this way and using this image we can eliminate long objects by expertly sifting (whose shape factor is below 0.4). The result is a new image in which we shall only perceive the areas with alveolar erosion $(\boldsymbol{A V})$ and pits $(\boldsymbol{P I})$ which have usually a globular or circular form (high $F_{f c}$ ). Inverting the expert sifting process $\left(F_{f_{c}}>0.4 \%\right)$ we are left with another image with striations $(\boldsymbol{E T})$, grooves $(\boldsymbol{A C})$, fissures (FS) and plaques (DP).

This whole process normally gives us three images. The first one with $\boldsymbol{E N}$ and $\boldsymbol{P T}$, which will be reassigned a new colour. The second one, with areas of $\boldsymbol{A} \boldsymbol{V}$ and $\boldsymbol{P I}$ with another different colour. And the third one with areas of ET, AC, FS and DP which, as with the others, will be given a new colour. These images are combined in one area of memory, by addition processes (11). Thus, obtaining just one image showing the layout of the alteration forms in the monument.

Normally, and due to the fact that the $\boldsymbol{A} \boldsymbol{V}$ and $\boldsymbol{P I}$ appears as small areas, the whole ashlar has been marked in order to make the task easier, dependeing, of course, on the working scales and the operation resolution. 


\subsection{Mapas o Niveles de Informacion}

Llamamos capa a aquella imagen o imágenes, generadas o deducidas, que contienen información gráfica, asociada a una base de datos relacional y que pueden combinarse con otras imágenes o entre sí.

Las capas de información se establecen con las imágenes elaboradas por tratamiento digital, asignándole el nivel cero a la imagen esqueletizada (imagen máscara), que es la que contiene los datos de referenciación con el resto de los mapas; es decir, la que nos da los sillares tal y como están en la actualidad, repitiéndola en todas las capas que, posteriormente, generemos. Este nivel es el que sirve de referencia para su conexión entre ellas, en recintos comunes de memoria de trabajo (superposición de la información). La litología es una capa generada en el procesado de la imagen, por clasificación de los materiales, y se utiliza como recinto de memoria para conectarlo con una base de datos (7) con las propiedades petrofísicas, hídricas y petrográficas, deducidas por otros métodos (ensayos petrofísicos, microscopía etc..) y que exceden este trabajo. Cada litología se identifica, por consiguiente, con un nivel de gris específico y sólo con uno.

Las propiedades petrográficas, hídricas, etc., se introducen en una base de datos cuyo código de identificación y entrada es el mismo que corresponde al nivel de gris identificativo de esa litología (15). De esta forma, y al desplazar el cursor sobre la pantalla del monitor y pinchar un pixel determinado, éste lee su "color" correspondiente y da entrada a la base de datos que, en una ventana de diálogo, muestra las propiedades que contiene. Una segunda posibilidad, asimismo, es introducir "vía teclado" el rango de valores de una determinada propiedad (porosidad, por ejemplo) que discrimina los colores identificativos de la litología correspondiente, representando, en pantalla, aquellos colores que estén comprendidos entre ese rango, dando lugar a mapas cartográficos de propiedades petrográficas, petrofísicas o hídricas. Esta segunda posibilidad se conecta, siempre, sobre la imagen máscara, dibujándose mapas temáticos de propiedades (6). Cada uno de ellos, así deducido, puede aislarse y añadirse a una nueva capa de información (Fig. 1e).

Los mapas de información, proporcionan la cartografía de las alteraciones del monumento, y se corresponde con la imagen, o imágenes, deducidas en los últimos procesos del tratamiento de imágenes.

La combinación de estas imágenes, recuperadas en recintos de memoria, con cualquier otra capa (litológica, alterográfica, etc.) da mapas de áreas de intersección que facilitan la interpretación entre los

\subsection{Maps or Levels of Information}

Layer is what we call an generated or deduced image, which contains graphical information associated with a relational database and which can form combinations with other images or with its own components.

The layers of information are made up of images elaborated by digital processing. We assign the level zero to a thinning image (mask image), which is the one containing the reference information for the rest of the maps. That is to say the one that shows us the ashlars exactly as they are nowadays. This level shall be repeated in the rest of the layers we create afterwards. This level is the one which acts as a point of reference for the connection among these layers, in shared areas of working memory (information superposition). The lithological layer is the derived from the classified image of the materials. It is used as an area of memory to connect it to a database (7) containing the petrophysical, water and petrographical properties, which are derived using other methods beyond the scope of this paper. As a consequence each lithology is identified by a specific grey scales and only with one.

The petrographical, water, petrophysical and other properties are introduced in a database whose identification and entry code is the same, corresponding to the identifying grey levels of that lithology (15). In this way when the cursor is moved across the monitor screen and a certain pixel is selected the corresponding "colour" is read and the database is accessed. A dialogue box is opened and the pixel's properties are shown. Likewise, a second possibility is to introduce "via the keyboard" a range of values for a certain property (porosity, for example) which distinguishes the identifying colours of the corresponding lithology, representing on the screen those colours which fall within that range. This technique permits that cartographic maps of petrophysical and water and petrographical properties were generated. This second possibility is connected, alway, over the mask image, producing thematic property maps (6) with the values a databases. Each of them, produced in this way, may be isolated and added to a new layer of information (Fig. le).

The information maps show the process of the alterations of the monument and are corresponded to the image produced in the last image processing action.

The combination of these images retrieved in areas of memory, with any other layer (lithological or alteration graph) provide maps of intersection areas which enable us to relate the petrophysical, water and 
parámetros petrológicos, petrofísicos, hídricos, etc., y las alteraciones, descamaciones, etc.. De gran utilidad a la hora de proponer restauraciones, rehabilitaciones o sustituciones de unos sillares, o elementos constitutivos, por otros.

A modo de ejemplo, se han combinado tres capas de información, dos generadas (la naturaleza del monumento o litología), su estado (alteración), y una deducida (porosidad del material) (Fig. 1f). El procesador señala tres zonas que se corresponden con los sillares que deben sustituirse, restaurarse, por tratamiento con algún producto, limpieza, etc., y los que no presentan importantes daños.

\section{CONCLUSIONES}

La utilización de las técnicas de proceso digital de imágenes, asociadas a una base de datos que incluya parámetros petrográficos, petrofísicos, etc., para la generación de mapas temáticos (sistema de tratamiento de la información) permite elaborar cartografías (alterografias, degradación de materiales, litologías, etc.), que facilitan la interpretación y evaluación de las patologías del monumento estudiado.

La utilización de este sistema en algunos edificios histórico-artísticos de nuestro patrimonio, ha posibilitado la clasificación de los sillares, de forma rápida y objetiva, con vista a una primera evaluación de su estado y proponiendo qué partes deben tratarse, sustituirse o mantenerse, generando mapas temáticos de gran interés en las tareas de rehabilitación, limpieza, consolidación etc., con un considerable ahorro de tiempo y ordenación de las fases a realizar. petrographical properties with to alterations, decoherences, etc.. This is of great use when the time comes to propose restorations, renovations or substitutions of some ashlars for others, or structural elements.

As an example, three levels of informations are been combined; two generated, litologhy, its state (alterations), and one deduced (porosity) (Fig. 1f). In which the processor marks the ashlars that should be substituted, restored (treated with some product or cleaned) and those that show no signs of serious damage.

\section{CONCLUSIONS}

The possibility of combining digital image processing techniques to generate thematic maps, with a database containing petrophysical, petrographical parameters, etc., constitutes a data processing system which allows to produce specialized maps (of alterations, decomposition of materials, lithologies, etc.). This facilitates the interpretation and evaluation of the pathologies of the monument in question.

The use of this system in some of our historical-artistic heritage, has allow the classification of the ashlars, giving us a first approximation of which ones should be treated, substituted or maintained, as well as providing us with thematic maps of great interest in the tasks of renovating, cleaning, consolidating, etc., with the significant save of time and the organization of the phases to be carried out.

\section{BIBLIOGRAFÍA}

(1) BEL-LAN, A., (1984): “Análisis de parámetros petrográficos mediante proceso digital de imágenes”. Tesis Doctoral. Fac. Geol. Univ. Oviedo. pp. 135.

(2) BEL-LAN, A.; MONTOTO, L.; MONTOTO, M., (1978): "Digital processing of microscope images: quantification of petrographic parameters related to the quality of cristalline stone". Int.Symp. on Det. and Prot of Stone Monuments, UNESCO. Paris, sec. 5-2. pp. 1-20.

(3) LACUBE, J.; BISSAINTE, M.;HERNANDEZ, J., (1993): “Treatment d'image appliqué aux materiaux: Exemple d'une analyse quantitative des feldspaths dans les roches". Bull. of Int. Assoc. of Eng. Geol. $n^{\circ}$ 47. pp. 109-17.

(4) MENG, B., (1990): "Resolution-dependent characterization of interconnected por systems: development and suitability of new method". Mat. and Struct. $n^{\circ}$ 27. pp. 63-70.

(5) ZEZZA, F., (1990): “Computerized analysis of stone decay in monuments". Atti del $\mathrm{I}^{\circ}$ Simposio internazionale. Bari (Pavia). pp. 163-84.

(6) BILL, R.; BÜHLER,W.; ROBIN,A; MCLAREN, B., (1992): "Thechnical evaluation of GIS-product. Workshop notes. 3th European conference and exhibition on GIS". EGIS-92. Vol. 2. p. 62. 
(7) WALSH, S.J., (1988): “Geographic Information Systems. An instructional tool for Earth Science Educators”. Journ. of Geogr. pp. 17-25.

(8) MONTOTO, L., (1982): “Digital multi-image analysis: Aplication to the quantification of rock microfractography”.IBM. Journ. of Res. and Dev. Vol. 26, pp. 734-45.

(9) ANGEL, Ma .C., MARTÍNEZ, B. \& PRENDES, N., (1995): "The evaluation, using digitized images, of the deterioration of the ashlars of the old brigde in Molina de Aragón (Guadalajara)". pp. 22-33. VI Simpo. Nacion. de Rec. de formas y Anal. de Imágenes. Tomo I. pp.93-162.

(10) RUSS, J.C., (1991), “Computer-Assisted microscopy. The measurement and analysis of images". Plenum Press. N.Y. Chptr 3. pp.33-69.

(11) ROCA, X.; SANCHEZ, X.; SERRAT, J.; VANRELL, M.; VILLANUEVA, J.; VITRIÀ, J., (1991): “Curso de tratamiento y análisis de imágenes". Chptr.3, pp. 63-65 y Chptr.5, pp. 161.

(12) COSTER, M.; CHERMANT, J.L., (1985): "Précis d'analyse d'images". Ed. du Centre Nat. de la Rech. Scient. Chptr X. pp. 33580.

(13) DOMINGO, A., (1993): “Tratamiento digital de imágenes”. Guía monográfica ANAYA. Chptr 4.pp. 80-83.

(14) ZEISS IBERICA, (1984): "Proceso y análisis de la imagen". Series monográficas. V.Reconocimiento de Estructuras. Users Guide. 35pp.

(15) ANGEL M $M^{a}$ C., (1994): "Aplicación de la teledetección en la localización de superficies de agua. Monografia del CETA". Ed. del CEDEX-MOPTMA. pp. 40-45.

(10) ESBERT, R.M.; GARCÍA RAMOS, J.C.;NISTAL, A.M.; ORDAZ, J.; VALENZUELA, M; ALONSO, F.J. SUAREZ DECENTI, C., (1992): "El proceso digital de imágenes aplicado a la conservación de la piedra monumental. Rev. de Arqueología". Año. XIII, $n^{\circ} 139$. pp. 7-12.

(17) DE FRUTOS BORREGUERO, M., (1992): "Epoca y Conservación del acueducto de Segovia”. Ed. ARTHAX, S.L., pp. 78-96.

(18) SEGOVIA, F., (1995): “Cartografía de Monumentos por tratamiento digital de imágenes. Por el bien de la piedra". Rev. MOPTMA, $n^{\circ}$ 436. pp. 54-64.

(19) PALOMO, A., (1995): “Agentes agresivos y mecanismos de deterioro en materiales de construcción”. Semin. CEMCO-95. XIII Curso de Estudios Mayores de la Construcción. pp. 1-5.

(20) ESBERT, R.M.. (1995): "Deterioro de materiales pétreos". Semin. CEMCO-95. XIII Curso de Estudios Mayores de la Construcción. pp. 38.

(21) BEUCHER, S., (1993): "Segmentation tools in mathematical morphology". Chp. 2.6. pp. 443-56. Handbook of Pattern Recognition \& Computer Vision. Ed. Chen, Pau \& Wang.

(22) CEDEX, (1991): “Aplicaciones del tratamiento digital de imágenes”. Serie Monografias. CEDEX-MOPTMA. 331 pp.

(23) DE LAS CASAS, M., (1986): "Mas allá de lo pintoresco". Editorial de la revista MOPU. p. 3. Guía de la Arquitectura popular en España. no 334.

(24) ESBERT, R.M. AND MONTOTO, M., (1986): "Digital Computering of microscope images petrographic investigation of stone". ICOMOS. Group petrography. Pavia Meeting. Sep. 1986. pp. 24.

(25) FITZNER, B., (1990): "Mapping of natural stone monuments. Documentation of lithotypes and weathering forms". Advances workshop: Analytical methodologies for the investigation of damaged stones, Pavia (Italia).

(26) HOLGADO, M., (1989): “Gigantes con pies de barro. Deterioro de edificios por el mal de piedra”. Revista MOPU, noviembre. pp. 6-12.

(27) JURADO,F.,(1994): “Acueducto deSegovia: documentos para una restauración”. Informe. Revista Restauración \& Rehabilitación. $\mathrm{n}^{\circ} 1$, sept. oct. pp. 17-31. 
(28) MARTÍNEZ, A., (1993): “Discriminación, cuantificación y cartografiado de componentes petrográficos mediante proceso digital de multi-imágenes microscópicas”. Tesis Doctoral, 235 pp. Universidad de Oviedo.

(29) MILLER, M., (1995): “Maya Masterpiece Revealed at Bonampack”. pp. 50-69. National Geographic. Of. Journ of the Nat. Geogr. Society. February. vol. $187, \mathrm{n}^{\circ} 2$.

(30) PICARDO, J.L., (1994): "Sobre la teoria de la restauración". Revista Restauración \& Rehabilitación. sept. oct. pp. 64-66.

(31) TUCERYAN, M. \& JAIN, A.K., (1993): "Texture analysis". Chp. 2. 1. pp. 235-76. Handbook of Pattern Recognition \& Computer Vision. Ed. Chen, Pau \& Wang.

\section{publicación del IETCC/CSIC}

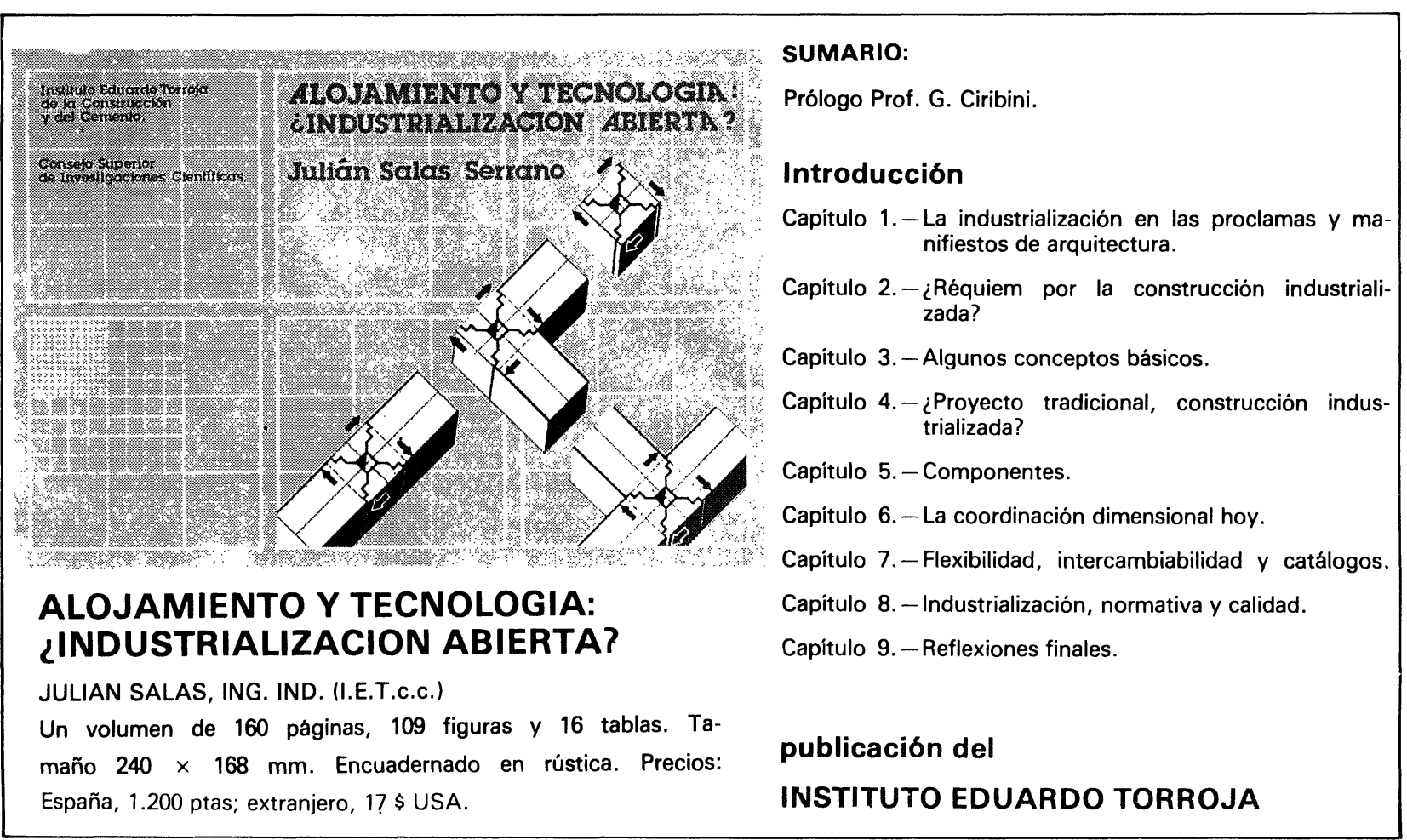

